\title{
An Exploration of College Students' Trustworthiness Education by Chinese Excellent Traditional Culture
}

\author{
Meng-jiao LI \\ Tianjin University of Technology,Tianjin300384,China \\ 447272954@qq.com
}

Keywords:Excellent Traditional Culture;College Students;Trustworthiness Education.

\begin{abstract}
Trustworthiness is a great tradition of China, and it is very important for universities and colleges to execute trustworthiness education. This paper makes a summary on the argument related to trustworthiness and summarizes the status and reasons of trustworthiness deficiency from college students.And the methods of trustworthiness education of college students are proposed from the perspective of excellent traditional culture to make contribution to promoting college students trustworthiness education.
\end{abstract}

\section{Introduction}

Chinese narion own over-five thousand years culture and history accumulation, where exists plenty of valuable ethics and good qualities. And these provide modern education with good models. As the important force in national and social development, the quality of the education of college students will directly influence the future ideological and moral standards of the all citizens.

\section{The Trustworthiness of Chinese Excellent Traditional Culture}

China is famous as the state of ceremonies all over the world, trustworthiness means being honesty and faithful, which is one of the most important characteristics of Chinese ethics. There exist many records related to trustworthiness in traditional culture, the concept of "honesty" firstly appeared in the Book of Documents. In Confucian thought, Confucius said,“ I do not know how a man without truthfulness is acceptable." Confucius thought that ideal talent must have both ability and integrity. The trustworthiness was also permeated in Legalism thought. Shang Yang who was the Representative of the legalism said, "There are three methods to running the country, the first one is law, the second one is honesty and the third one is power." He pointed out that honesty was a useful tool to govern a country. Whether it is to behaving oneself, communicating with others or doing things or running a country, it is obvious that good faith cannot be absent in excellent Chinese traditional culture . Good faith is one of the most important standards of ethics[1].

\section{The Necessity of Strengthening the College Students' Trustworthiness Education by Chinese Excellent Traditional Culture}

Excellent Traditional Culture is An Important Kind of Thought Resources for College Students' Trustworthiness Education. Chinese civilization of five thousand year is the foudation of national culture and tradition. It plays an important role in modern society. The trustworthiness which is an important moral quality has always been a valuable spiritual wealth of our country since 
ancient times. College students' trustworthiness education in new era must be inseparable from our history and traditional culture[2].

College Students' Trustworthiness Education is the Inheritance and Development of Excellent Traditional Culture.Morality is the soul of culture. In the process of inheriting and developing the excellent traditional culture, trustworthiness plays a key role. Only Colleges pay attention to college students' trustworthiness education and develop college students' quality of obeying moral code, the essence of excellent traditional culture can be better inherited and developed.

Trustworthiness Education is the Basic Quality of College Students. Trustworthiness is one of basic moral standard of citizens, morality is the core content of the spiritual civilization construction. College students not only need to study hard on professional knowledge, but alos need to receive moral education. Morality is the foudation of comprehensive qualities of college students. Strengthening college students' trustworthiness education meet the requirement of our national spiritual civilization construction.

\section{The Current Situation and Reasons of College Students' Trustworthiness Deficiency}

College students are burdened with the historic mission of building our motherland. Therefore, the thought and behavior of college students is particularly important. The analysis of the symptoms and reasons of college students' trustworthiness deficiency is good for solving the problem efficiently.

Current Situation.The vast majority of college students are able to adhere to honesty, but there are still some lack of trustworthiness which cannot be ignored. The symptoms are as following.

Cheating in Exams. Although the treatment of cheating is very strict, lack of hard-work as well as poor knowledge accumulation of some students in usual time brings high dishonest frequency and the problem is serious.

Academic Plagiarism. Some students don't pay attention to academic accumulation in usual time.So they often chose to copy the existing result from the Internet or something else in the process of completing theses and practice reports. This behavior can't show students' real level of studying and seriously influence the academic quality.

Credit Level. For the convenience of students successfully in poor areas completing their education, the nation provides college students with loans and preferential lending policies. But there are some college students who have the economic empowerment not to repay on schedule after graduation. Weak credit consciousness of college students is one of the important causes of this phenomenon.

Job Search. Job resume is an important part of students application. Many students choose to create false documents and fictional experience to become dominant in the highly competitive job market for himself, which make many employers distrust college students.

Interpersonal Communication. Some college students are influenced by negative factors of social environment. They show a strong utility, do not tell the truth and break their promises, which leads to distrusting each other. All of the mentioned above greatly damage the harmonious development of college students interpersonal relationship.

Reasons. There are many reasons why college students are trustworthiness deficiency. This paper will make an analysis from individual, family, college and society aspects.

Personal Reasons.Firstly, trustworthiness awareness of some college students is weak and they are influenced by bad social trends. Secondly, some students show bad performance in self-control. 
They cannot control their-selves facing temptation. Thirdly, some college students don't have moral belief and will do trustworthiness deficiency behavior.

Family Reasons. Parents are the first teachers for children. Parents' education directly affects the ideological and moral standards of children. Some parents are poor in ideological and moral standards. They have misconceived educational concept, which makes children develop dishonesty thoughts .

College Reasons. There is a lack of a complete and effective educational system of moral education in colleges. The teaching methods and contents of trustworthiness education are boring, which brings weakening trustworthiness education.

Social Reasons. Reform and opening up brings economic globalization and high frequency of culture exchanges between countries, as well as negative effects. College students are in the stage of world outlook, life outlook and value outlook formation, so they have weaker resistance to bad ideas. The unethical practices have an impact on college students trustworthiness education [3].

\section{Methods for College Students' Trustworthiness Education by Chinese Excellent Traditional Culture}

Chinese excellent traditional culture provides college students' trustworthiness education with a wealth of education resources in the new era. Using excellent traditional culture to cultivatem trustworthiness education should become an important part of trustworthiness education in the colleges.

Cultivating College Students' Trustworthiness Concepts. Traditional Chinese culture treats trustworthiness as the basic moral character. Students should study scholarly research of ancient Chinese trustworthiness thought and cultivate the down-to-earth quality. Sudents can establish honest attitude gradually.

Paying Attention to Trustworthiness Education in Classroom.Combining excellent traditional culture with trustworthiness education in the classroom is the most direct and effective way. Universities should set up curriculum of traditional culture, such as history of Chinese culture, traditional morals and so on. In addition, colleges should try more methods and use them comprehensively to vividly reflect the trustworthiness education of traditional culture.

Creating a Good Environment of Trustworthiness Education.Creating a good faith campus atmosphere has subtle influence on trustworthiness education of college students. Colleges can utilize many methods of strengthening excellent traditional culture and good faith construction in campus culture, such as building up related Web sites, organizing traditional culture quiz.

Perfecting the Reward and Punishment Mechanism. Credit files should be established for each student which regulate and controll students behavior through score record. Meanwhile, the establishment of evaluation mechanism on honesty of college students and completing corresponding system of rewards and penalties will arouse the students' attention to the trustworthiness[4].

Encouraging Students to Participate in Practical Activities.Encouraging students to actively participate in school activities and social practice will make the trustworthiness education perfect. Establishment of trustworthiness concept is inseparable from practice. Only through practicing, checking themselves and correcting themselves, college students can really own moral character of trustworthiness. 


\section{Summary}

College students' trustworthiness education is a large and complex project. The whole society should pay attention to the trustworthiness education. This is an inevitable choice for college students to improve themselves and adapt to the future society.

\section{References}

[1]Weili Fu,Dan Wang,Lei Liu,Dexian Li.The Component Characteristics of Integrity Outlooks and Its Enlightenment for Integrity Education[J]. Educational Research, 2010, (01): 44-49.

[2]Heping Ma.The Value of Traditional Thoughts in College Students Trustworthiness Education[J].Journal of Wuhu Vocational Institute of Technology, 2011(04).

[3]Juqing Fang, Hui Fang, Dan Zhu. Traditional Ethics and College Students' Trustworthiness Education[J]. China Youth Study, 2010, (08): 93-95.

[4]Dongyang Li. Research on Problems and Countermeasures of College Students' Honesty Education[D]. He Nan: College of Ideological and Political Education of Henan University of Technology, 2012:29-32. 